\title{
Small and Middle Macro Enterprise (SME) Preference in Making Financing Source from Micro Financial Institutions: A Research on SME Preference Identification in Making Financing Source from Micro Financial Institutions
}

\author{
Sri Utami ${ }^{*}$, Cintya Hartanti, Hery Purnomo, and Anastasia Adiwirahayu \\ Sekolah Tinggi Pembangunan Masyarakat Desa “APMD” Yogyakarta, Jln.Timoho \\ 317 Yogyakarta, 55225 Telp.0274 561971, Indonesia \\ *sriutami211159@gmail.com
}

\begin{abstract}
SMEs is one component driver of economic growth in the city of Yogyakarta. The position of SMEs as one unit of economic activity that is supported by the presence of Microfinance Institutions. Microfinance Institutions consist of the bank (Bank Unit Micro and rural banks) and non-banks (cooperatives and BMT) under the supervision of Bank Indonesia. In this study see the pattern of preferences and the factors that influence the preferences of SMEs in seeking sources of financing of the Microfinance Institutions. To obtain data about the preferences and perceptions of the MFI MSME used cluster random sampling by distributing questionnaires and structured interviews with a sample of SMEs in the city of Yogyakarta, especially SubDistrict and District Umbulharjo Kotagede. Meanwhile, the questionnaire was also given to MFIs (Microfinance Bank Unit, rural banks, cooperatives, and BMT) to see their perceptions of SMEs. The data was processed using descriptive statistics and will be interpreted quantitatively and qualitatively. The results of the analysis of the preferences of respondents in general, there is a decisive factor selection MFIs by clients (SMEs) on each MFI forming the segmentation. The conclusion that the differentiated banking MFIs (Micro Business Unit Commercial banks and rural banks) and non-banking MFI (Credit Unions and BMT).
\end{abstract}

Keywords: Preference, UMKM, LKM

\section{Introduction}

Indonesia macro economy description can be identified by seeing some macro-economic indicators, such as real sector investment. It can become the indicator which can identify the direction of macro-economic growth and policy [1]. Individuals' expectation improvement towards return on investment will increase the investment climate and real sector. Real sector investment increase will indirectly increase the demand towards goods and services. Societies' demand towards goods and services which aggregately increase will be the stimulant for producers to increase their production capacity and innovation in creating a product. The process of real sector investment increase indirectly pushes societies' economic growth and welfare. The role of banking as the intermediation institution which channels party with excess fund to them who need it in the society. However, the role of informal financial institutions has

Article history:

Received (December 21, 2019), Review Result (January 26, 2020), Accepted (April 5, 2020) 
Small and Middle Macro Enterprise (SME) Preference in Making Financing Source from Micro Financial Institutions (A Research on SME Preference Identification in Making Financing Source from Micro Financial Institutions)

more proportion than formal banking. In its development, informal financial institutions are acceptable by entrepreneurs, especially Small and Medium Micro Enterprises (SMME).

Based on SMME actors, informal financial institutions can be more acceptable because its flexible characteristic, especially in requirement and amount of loan which is not as strict as the formal banking [2]. It is as one of indicators that the existence of informal financial institutions requires SMME. Therefore, informal financial institution is known as Micro Financial Institution (MFI). The development and existence of MFIs in national economy has not had clear realm and status. Some formal micro business units such as Bank Micro Unit, Rural Bank (BPR) or micro units in some public banks have clearer realm and status because they are organized in Indonesian Banking Architecture (API). Even the government has Deposit Insurance Corporation (LPS) which strengthens the existence of formal baking micro business units.

Some empirical data indicates that Microfinance Institutions (LKM) have role to enable SMME performance and push national economy. In general, the contribution of SMME to Indonesia economy macro growth indicated increase during the period 2000-2005. Based on Bureau of Statistics (BPS), the Indonesian GDP which came from the SMME performance reached IDR 1,013.5 trillion (56.7 percent of GDP). The amount was supported by 42.4 million SMME business units and absorbed 79 workers. On the other side, banking intermediation function towards real sector development can be seen from the Loan to Deposit Ratio (LDR). It is a comparison between the ratio of fund channeled to the societies (third party) in form of credit or loan and their fund (third party) to public bank in form of saving. The level of banking LDR in a certain country or region can be the banking intermediation performance in the area. Banking intermediation performance will indirectly influence the real sector of a region.

The phenomenon of credit demand tendency of increasing micro business unit and small scale should be responded with the existence of micro financial institution. So far, some public banks have participated in responding to this phenomenon by forming a microbusiness unit and perform program linkage with micro financial institutions (for example some parties who participate in responding credit demand in Yogyakarta city) become an interesting matter to be observed. The competition among public banks, rural banks (BPR), Kosipa and Microfinance Institution will become an interesting analysis besides the customers' preference pattern in their credit need access. A research on customers' preference in selecting credit access alternative as their financing source of Microfinance Institution will be interesting applied in Yogyakarta city, specifically in two sub districts, which are Kotagede and Umbulharjo sub district as the question proposed in this research focus. Using the question, the objective of this research is to identify societies' selection factor on both banking or non-banking micro financial institution in Yogyakarta. In the modern economic development dynamic, information on customers' preference in finding microfinance institution financing is a business decision. The benefits are first, the information on market segmentation of micro financial institution and the cause of segmentation, whether Micro Finance Institution is stronger than SMME so that it is more flexible to select debtor candidates or vice versa. Providing feedback to each financial institution in determining credit marketing strategy so that it does not only serve more customers but also have as low as Non-Performance Loan (NPL) as possible [3]. The rest of this paper is organized as follow: Section 2 describes the Conceptual Base. Section 3 describes the Research method. Section 4 presents the obtained results and following by discussion. Finally, Section 5 concludes this work

\section{Conceptual base}




\subsection{SMME basic concept}

The establishment of new business and motivation towards entrepreneurship culture are central issues in many areas in Indonesia, especially Kotagede and Umbulharjo sub disticts in Yogyakarta. The issues become the alternatives of an area economic growth. High real sector investment mobility pushes an area to separate from foreign investment dependency in increasing the societies' welfare. Some evidences also indicate that new business establishment through entrepreneurship contributes towards work field, politic and social stability, economic innovation and development. Small enterprises in a developed country are defined as businesses which serve customers in narrower scope especially in local scope [4]. Small enterprise has characteristics such as: (1) small enterprise management is individual; (2) the capital ownership is possessed individually and/or by small group; (3) small business marketing area is local around small enterprises; and small relative enterprise capacity size.

It its implementation, the concept of each SMME definition in Indonesia is vary from one to another. Some definitions which have been proposed by some institutions have different approach. Some definition differences can be summarized as follow: (1) Bureau of Statistics (BPS) utilizes workers who are employed as the differentiator criteria of Small and Medium Micro Enterprises; (2) Industrial Department uses financial criteria base in form of capital goods and per worker investment; (3) Bank of Indonesia utilizes asset and financial criteria as the differentiator among business types of Small and Medium Micro Enterprises. (4) Department of Industry, Trade, Cooperative and Agriculture (Deperindagoptan) utilizes trade business active capital as the differentiator of SMME types; (5) Besides, there is comprehensive criteria made by the World Bank to differ SMME and uses workers, asset and turnover criteria in parallel.

\subsection{Classical theory of SMME development}

Review of SMME theory development, a type of SMME which is utilized as general reference is SMME business type which output is consumer goods and/or raw material which support industry. SMME has product differentiation compared to big-sized industry. Therefore, naturally SMME is able to create their potential market. In the classical theory, SMME development is more caused by the entrepreneurs' ability to see new potential market, both it is consumer or supporting goods/items and manufacture industry. A study which was performed in developing and developed countries were successful to identify three dominant factors of SMME forming, such as: location factor, production process and output market. The factor differences influence condition difference of each SMME in each subsector on certain sectors. While Saranga in [5] explained that two natural factors which cause business scale are market and technology.

The success key of SMME survival ability is its characteristics which have low production cost. While Koszalka in [6] and Hilson in [7] saw the typology of SMME development consistently in line with economic development phase development which within this matters have three phases, such as First Phase, a stage in which most of SMMEs move in agricultural and home industry sector. Rural location is the location of most of developing SMMEs. Second Phase, the stage of shift from small to bigger business scale. In general, SMME on these phases are SMMEs which support big industries. Ates in [8] mentioned that urbanization factor is the key factor of SMME shift from first to second phase. Third phase is a phase when SMME leaves SMME category into big industry that has more permanent organizational structure. The development of business, management, marketing and distribution channel have been greatly 
Small and Middle Macro Enterprise (SME) Preference in Making Financing Source from Micro Financial Institutions (A Research on SME Preference Identification in Making Financing Source from Micro Financial Institutions)

distributed. In this phase, the access towards financial infrastructure, intensive system, subsidy and various government commitments are the main driver factors.

\subsection{Modern theory of SMME development}

An outstanding issue on SMME development is flexible specialization theory development. This theory development is based on the response towards global economy condition. Piore and Sobel in Jessop, in [9] identified that there are four characteristics of flexible specialization, such as :

A. SMME in community can adapt in production technique but specialize on certain goods type.

B. Market entry limitation.

C. High Innovation with competence level

D. Good cooperation level among SMMEs (collaborating SMMEs)

The main factor which shifts classical to modern theory paradigm is globalization. Globalization impacts the change of production organizational method, employees and market. Globalization causes the shift from mass to special production direction. In this condition, the market opportunity is higher. Empirical evidence in many countries or areas is SMME can use the market opportunity as its output, on the other side, SMME ability to organize with new method can maximize the condition in line with the entrepreneurship concept [10].

\subsection{SMME and capital}

The superiority and opportunity of SMME is to dominate manufacture market by producing raw components of certain products. Besides, SMME activity is assumed to push fabricating material goods. It indicates SMME ability to create product differentiation. The SMME position will have more competitive advantage and superiority than financing program with relative ease and guarantee terms which are relevant with the condition or ability of SMME.

Capital is one of requirements of SMME success among other requirements such as managerial, technology, marketing and raw material availability [11]. However, recently SMME activity can be performed without finance. For a company, capital is required for operational financing; daily activities such as raw material purchasing, wage and salary expense, treatment and maintenance, electricity, telephone and water bill, etc. Capital is also required to buy fixed assets. These various sources form capital structure.

Theory which explains optimal capital structure for the company is trade of model theory. This theory states that optimal capital structure is the balance achievement between tax shield of leverage and financial distress and agency cost of leverage. This model implicitly states that the company does not utilize investment funding accompanied with bad loan. The best decision is moderate decision which considers funding instrument.

Through the model, it enables three conclusions of loan modal uses. First, corporation with lower business risk can borrow higher without bearing expended cost financial distress, so higher tax profit will be obtained because higher loan use. Second, corporation which has tangible and marketable asset can use higher loan. Third, state corporation which high tax level should make higher loan within the capital structure than corporation which pay the tax on the lower level because the interest is acknowledged by the government as the cost that reduces revenue tax.

Furthermore, Martins in [12], assumed that credit portion causes credit market failure which is indicated by adverse and moral hazard. Adverse selection is credit market failure because the 
interest rate increase which causes the high-risk taker creditors to take the loan. While moral hazard occurs because the creditor is pushed to take higher risk. This position indicates that bad credit risk is positive function of interest rate and uncertainty degree in financial system.

\subsection{SMME preference towards micro finance institution}

In the perspective of relationship pattern between corporation and customer, the relationship between SMME and Finance Institution is analogized as a relationship pattern between corporation and customer. In the pattern, finance institution is positioned as temporary corporation and SMME as the costumer. Specifically, each SMME needs capital. One of capital sources comes from loan which can be obtained through credit demand to finance institution. The credit is intended to pay work capital and investment activity. Credit for work capital is performed for production, marketing, raw material procurement and supporting process. Investment credit is intended to pay machine, factory facility, technology development requirement etc.

The source of credit for SMME comes from Micro Finance Institution (MFI). It is intended that this finance institution is an institution which is involved in micro credit. According to Microcredit Taiwo in [13], micro credit is small scale credit provision program given to lowereconomic societies to fund productive activity which can be done by themselves and their family. Bank of Indonesia (2001) defined micro credit as a credit granted to both individual or group productive business actors who have the highest revenue IDR 100 million per year. Meanwhile, Bank Rakyat Indonesia defined micro credit as credit service which amount lower than IDR 50 million.

Based on the form, in general, Micro Finance Institutions (MFI) are divided into three Saleh in [14], which are: (1) formal institutions such as rural banks and cooperatives, (2) semiformal institutions such as non-government organizations, and (3) informal sources such as debt relief. While Paulus in [15] divided MicrofInance Instituions into four big categories: (1) formal MFIs both it is bank or non-bank; (2) non formal MFI, both it is incorporated or nonincorporated; (3) government Microfinance Isntitution; and (4) informal MFI such as loan shark or saving and loan gathering. Bank of Indonesia only divided MFI into two categories, such as bank and non-bank MFI. This category difference can occur because of utilized criteria difference of legality or procedure aspect in each MFI operation.

Therefore, SMME is faced with various credit services from various micro finance institutions. Which institutions that will be used depends on SMME preference, especially SME in this research towards micro finance institution. It means, an SMME will decide to use one MFI of other MFIs because many reasons, such as easier procedures not only free from collateral but also low interest rate, realization speed, and many other preferences based on relevant SMME perception.

\section{Research method}

The populations are SMMEs in Yogyakarta City, especially in two sub-districts which are Kotagede and Umbulharjo sub district. Considering that this research is related to the SMME perception towards Micro Finance Institutions (MFI) on saving or loan, the target populations were SMMEs which have had relationship with MFI. The sample drawing was performed using survey technique, which is obtaining information on population parameter of some populations. The technique which was utilized was cluster random sampling because the element name list in the sampling framework of population was unavailable and the distance among analysis units were relative far. The first step in cluster random sampling was determining cluster. The 
Small and Middle Macro Enterprise (SME) Preference in Making Financing Source from Micro Financial Institutions (A Research on SME Preference Identification in Making Financing Source from Micro Financial Institutions)

intended cluster includes Bank MFI which consists of Public Bank and Rural Bank (BPR); and Non-Bank MFI which consists of Cooperative and BMT (Baitul Maal waTanwil). The MFI selection as the MFI was taken randomly (random sampling). The second step was sampling frame which was determined from each cluster MFI accompanied by its unit, SMME. Furthermore, the sample frame as SMME unit was taken as the sample. The sample size of each sampling frame was determined $25 \%$ of total customers. The sampling was performed in random sampling. The data and variables of research, primary and secondary data. The primary data was obtained from structured interview with questionnaire as the guideline. Structured interview with questionnaire guideline towards two main pillars concerning the research objectives are (1) SMME actors, especially SME actors micro finance institution which covers Rural Bank, Cooperative and BMT (Baitu Maal waTanwil) or as analysis unit of the research. Using structured interview, it was expected that the information depth which was obtained comprehensively was performed towards 50 SMMEs, especially SMEs in Kotagede and Umbulharjo sub-district. The comprehensive information description on the condition of SMME preference, especially SME towards MFI was obtained from respondents through primary data. In order to maximize the research output, the question structures found in customers questionnaire (SMME actors) or micro finance institution was designed to provide the following information:

A. Customer Questionnaire covers the following information:

a) General information (gender, age, education, work, average salary, family dependent, business age)

b) Respondents' knowledge on finance institution

c) Respondents' interest to connect with finance institution

d) Feasibility analyzed from finance aspect

e) Credit Use

f) Preference towards finance institution (procedures and workers' attitude)

g) Perception towards finance institution (interest rate and installment pattern).

B. Finance Institution Questionnaire

a) General Information

b) Credit Policy

c) Credit Distribution Obstacles

d) Credit Distribution Development Effort

e) Suggestion

Besides using primary data, this research also utilized secondary data. The secondary data was obtained from local government institution statistic data, rural bank (BPR), Bank of Indonesia and some previous research on SMME. The data analysis was performed using Statistic Descriptive and Non-Parametric Extensification Approach (discrete choice analysis). Descriptive Statistic Approach was aimed to draw a statistic conclusion which was appropriate with sample characteristic by using some statistic visualization Lind and Goldkuhl, in [16], among them was frequency (table and graphic) and a distribution center (mean, median, and mode). The size was assumed as relatively good by explaining that the central size of sample distribution is mean score because it does not depend on the data grouping. Mean score was obtained by dividing all observation sample data numbers with sample size (n) and the approach was non-parametric extensification (discrete choice analysis). The approach provided systematic step in identifying the impact of relative weight and attribute trade-offs which were indicated by selections performed by the respondents. Although in the beginning the approach 
was utilized in the analysis which was aimed to understand the customers' decision-making mode, it was applicable in some analysis which more emphasizes on economic analysis [17].

\section{Result and discussion}

\subsection{Descriptive analysis}

\subsubsection{Respondent's preference analysis (SMME) in saving their fund at MFI}

The analysis of SMME respondent in selection MFI as an institution to save their fund will be divided into two aspects, which are MFI selection and determinant factor preference in selecting MFI to save money. In the questionnaire, the respondents can select one of MFI selections to save their money. 50\% respondent chooses Saving and Loan Cooperative as MFI of fund saving institution. 10\% respondent chooses BRI Unit as the MFI. 10\% respondent chooses to save their money in BMT. On the other hand, 30\% respondent is classified into other categories that they save their money for operational. So they do not save their money in finance institution [18].

Based on the result of general MFI selection analysis, dominant MFI services/ products which become respondent's selection is saving and security insurance factor that become the main factors of respondents' selection determinant. Indicating fund saving aspect in MFI becomes an aspect which preference pattern can be analyzed [19]. SMME preference in saving the fund in MFI can be described that 53\% respondents assume that security insurance factor is their determinant main factor to save the money in MFI. Factor of near location with their domicile becomes the determinant main factor of $17 \%$ respondents to save the fund in MFI. Flexible service factor is selected by 22 SMME respondents. Interest rate and wide network of each selection is $4 \%$. On the other hand, room comfort and prestige do not become respondents' dominant factor to choose saving their money in MFI [20].

The difference of respondents' preference in selecting MFI in general by selecting MFI as the money saving place is seen on interest rate and flexible service factor. Service factor in the analysis of respondents' preference in saving the fund in MFI becomes the second dominant factor after security insurance [21].

\subsubsection{The analysis of respondents' preference of loan in MFI (Credit)}

The analysis of SMME respondents in selecting MFI as a place to borrow the fund is divided into two aspects, which are MFI selection and determinant factor preference in selecting MFI as one of options to borrow money. $40 \%$ respondents select Saving and Loan Cooperative as the MFI to borrow money. Meanwhile, 58\% respondents who select BRI unit as the MFI. Saving and Loan Danamon is selected by $8 \%$ respondents and $2 \%$ respondents select BMT. On the other hand, there are $32 \%$ respondents who are classified into other categories, which are respondents who select public bank and they who stated that they do not borrow fund in finance institution. The discussion of respondents' determinant main factor preference in selectin MFI as a place to borrow money can be described that $35 \%$ respondents assume that interest rate factor is the determinant factor for them to borrow money (credit) in MFI. 26\% respondents of SMME also choose flexible service as their attractiveness to borrow the fund in MFI. Near location becomes the determinant main factor of $13 \%$ respondent to borrow the fund in MFI. Fast administration becomes the main factor of $14 \%$ respondents' choice.

On the other hand, the other factors such as security insurance, branch network, room comfort and prestige do not become the respondents' dominant factor to choose borrowing the 
Small and Middle Macro Enterprise (SME) Preference in Making Financing Source from Micro Financial Institutions (A Research on SME Preference Identification in Making Financing Source from Micro Financial Institutions)

fund in MFI. However, $6 \%$ respondents choose another component which involves installment factor as the main respondents' selection to choose MFI as their credit place.

\subsubsection{The perception of SMME towards the main factor of MFI selection}

MFI selection pattern which is done by SMME is reviewed from two aspects, such as respondent as the fund depositor and creditor. Based on both aspects analysis, it can be seen that interest rate and service factor (respondent as creditor) and security insurance and service factor (respondent as the depositor) are the main factors of MFI selection by SMME. Factors which become the main determinant of SMME to select MFI will be analyzed exploratively to see the level of respondents' perception towards a factor.

The determinant main factor of MFI selection that will be analyzed exploratively consists of 4 factors, such as interest rate, credit procedures, installment pattern and service provided by MFI workers. Security insurance factor is not directly explored. The substitute factor that will be put in the analysis of perception is installment pattern and credit procedure factor. $77 \%$ respondents state that the present interest rate factor of MFI has been relevant with the respondents' perception. 65\% respondents stated interest rate is not an issue for them and $12 \%$ respondents assume the current MFI interest rate is appropriate for them to take credit. In credit taking process, they assume that the credit taking procedure which is offered by MFI is easy. Based on the result of research, it can be seen that $75 \%$ SMME respondents consider the current MFI credit procedures are easy and $20 \%$ of them perceive it is very easy. Credit that has been taken by SMME in extending their business development will be given back to MFI in form of credit installment pattern. It can be described that credit installment pattern which is offered by MFI has been relevant with SMME perception. 75\% respondents stated that the credit installment pattern has been relevant with their perception. Even $15 \%$ respondents state that it is very relevant with their perception. In general, 75\% SMME respondents perceive that the level of MFI worker's service is great and fun. Moreover, $17 \%$ of them stated that the service is very fun.

\subsubsection{The perception of micro finance institution (MFI) towards credit requirement}

Micro Finance Institution which consists of Public Bank Micro Unit, Rural Bank (BPR), Cooperative and Baitul Maal waTamwil (BMT) have a perspective concerning the requirements provided to debtors. In this problem context, debtors are SMME, especially SMEs that borrow funds for their business activities. The description that MFI perspective towards credit requirements which are given to customers are prevalent. Financial statement requirement becomes the first FMI selection with 19\%. It is followed by administrational comprehensiveness and incorporated requirements have $18 \%$ each. Collateral and permit requirements have percentage of $13 \%$ each, while other requirements such as payroll etc is only $6 \%$.

\subsubsection{The perception of micro finance institutions (MFIs) towards credit application}

Specifically, the perceptions of MFI towards major requirements of credit application can be explained as follow: (A) collateral ownership requirement, (B) proposal application of customer candidate requirement, (C) customer's financial performance requirement, (D) customer's credit performance requirement, (E) customer candidate's character requirement, and $(\mathrm{F})$ administrational comprehensiveness requirement. Each of them can be seen in the following: 
A. MFI perception towards collateral ownership requirement. 59\% MFI respondents stated the collateral ownership is important and $41 \%$ MFI respondents stated it is very important.

B. MFI perception towards customer candidate proposal requirement indicates 55\% MFI respondents that the credit proposal ownership of debtor candidate is important and the other $37 \%$ states it is very important. There are $8 \%$ MFI respondents' states that credit proposal is less important requirement.

C. MFI perception towards customer candidate's financial performance requirement indicates that 50\% MFI stated that debtor candidate's financial performance is important and $42 \%$ respondents stated that it is very important. While $8 \%$ respondents stated that financial performance is a less important requirement.

D. $11 \%$ MFI respondents stated that the debtor candidate's past credit performance is important and very important respectively. In general, MFI perception indicates that the debtor candidate's past credit performance becomes an important requirement for credit application.

E. MFI perception towards customer candidate's character indicates $55 \%$ respondents stated that the customer candidate's character is important. While the other $42 \%$ said it is very important. In general, the perception of MFI indicates that debtor candidate's character requirement becomes an important requirement for credit application.

F. MFI perception towards administrational comprehensiveness requirement indicates $75 \%$ respondents who stated it is important ad $25 \%$ stated it is very important. In general, the perception of MFI indicates that the debtor candidate's administrational comprehensiveness becomes a very important requirement for credit application.

\subsection{Partial discussion}

The discussion is performed based on the descriptive analysis as follow:

\subsubsection{Information on SMME profile as the customer}

MFI is analyzed based on the revenue, monthly individual revenue, household expense, business revenue, business entity type, business sector and business scale. The description of SMME profile can be seen on the following

Table 1. SMME profile as MFI customer

\begin{tabular}{|c|c|c|c|c|}
\hline & $\begin{array}{c}\text { Micro Unit of } \\
\text { Public Bank }\end{array}$ & Rural Bank (BPR) & Cooperative & BMT \\
\hline Individual Revenue & $>$ Rp 10 juta & Rp 5 - 10 juta & Rp 1 - 5 juta & $<$ Rp 1 juta \\
\hline Household Expense & $>$ Rp 5 juta & Rp 1 - 3 juta & Rp 1 juta-3 juta & $<$ Rp 1 juta \\
\hline Business Revenue & $>$ IDR 25 million & $\begin{array}{c}\text { IDR 15 - 25 } \\
\text { million }\end{array}$ & $<$ IDR 5 million & $<$ IDR 5 million \\
\hline Business Expense & $>$ IDR 25 million & $\begin{array}{c}\text { IDR 15-25 } \\
\text { million }\end{array}$ & IDR 5 - 15 million & $<$ IDR 5 million \\
\hline Business Entity & Individual & Individual & Individual & Individual \\
\hline Business Sector & Service & Industry & Service & Service \\
\hline $\begin{array}{c}\text { Owner's Education } \\
\text { Level }\end{array}$ & Bachelor Degree & Senior High School & Senior High School & Senior High School \\
\hline Business Scale & Small Business & Small Business & Micro Business & Micro Business \\
\hline
\end{tabular}

Source: Analyzed

\subsubsection{The identification of MFI societies' selection determinant}

The discussion of societies' determinant factor toward MFI will be started from societies' selection MFI type aspect; general selection tendency; selected MFI product; MFI selection to 
Small and Middle Macro Enterprise (SME) Preference in Making Financing Source from Micro Financial Institutions (A Research on SME Preference Identification in Making Financing Source from Micro Financial Institutions)

borrow fund (credit); and MFI determinant factors to borrow and save the fund. [Table 2] describes the type, product and general tendency of societies in selecting MFI.

Table 2. Types and MFI of societies' selection

\begin{tabular}{|c|c|}
\hline Item & Societies' Selection \\
\hline Type of MFI (in general) & Public Bank Micro Unit and Rural Bank (BPR) \\
\hline MFI Product & Credit and Saving \\
\hline Determinant Factor (General) & $\begin{array}{c}\text { Security Insurance; Fast Service; Location is } \\
\text { near to their residence }\end{array}$ \\
\hline Type Of MFI for loan & Public Bank Micro Unit and Rural Bank (BPR) \\
\hline Determinant Factor of Loan & $\begin{array}{c}\text { Relevant Interest rate; good service, fast } \\
\text { administration; location is near to their residence }\end{array}$ \\
\hline Public Bank Micro Unit and Rural Bank (BPR)
\end{tabular}

Source: Analyzed

[Table 2] indicates Public Bank Micro Unit as the societies' selection MFI. The societies asere conventionally use the role of MFI. In this case, it is described with credit and saving as the societies' selection of main MFI product. In general, societies' selection towards MFI is determined by factors of security insurance, fast service and near location. Societies' selection MFI can be reviewed more detail based on the use tendency. In general societies' selection MFI which is utilized in borrowing money is Public Bank Micro Unit and Rural Bank (BPR). Factors which influence societies' selection towards this matter are relevant interest rate, good service and administrational speed.

\subsubsection{The segmentation of SMME preference towards each MFIS}

Preference segmentation in MFI selection done by SMME as their customer will be seen based on the previous general factor and other factors which can be the determinant of SME selection. Based on the explanation of table 2, the general factors in determining the selection of MFI by SMME as the customer who borrows the fund are interest rate, great service, administrational speed, and near location. Besides general factors, other factors which influence the selection of MFI will be analyzed deeper. Table 3 describe segmentation of SMME preference towards each MFI. Factors of FMI selection determinants will be ranked based on the analysis.

Table 3. The priority sequence of MFI selection determinant in borrowing fund based on the FMI segmentation.

\begin{tabular}{|c|c|c|c|c|}
\hline & $\begin{array}{c}\text { Public Bank } \\
\text { Micro Unit }\end{array}$ & Rural Bank (BPR) & Cooperative & BMT \\
\hline Near Location & 1 & 1 & 5 & 5 \\
\hline Location is in the city & 8 & 8 & 7 & 7 \\
\hline
\end{tabular}




\begin{tabular}{|c|c|c|c|c|}
\hline $\begin{array}{l}\text { The Location is near to } \\
\text { the public transportation }\end{array}$ & 9 & 9 & 2 & 2 \\
\hline $\begin{array}{c}\text { Comfortable Waiting } \\
\text { Room }\end{array}$ & 4 & 3 & 6 & 6 \\
\hline Parking Area & 5 & 5 & 8 & 8 \\
\hline Great Service & 2 & 2 & 3 & 3 \\
\hline Broad Network & 10 & 10 & 10 & 10 \\
\hline Promotion & 6 & 6 & 4 & 4 \\
\hline Administrational Speed & 3 & 4 & 1 & 1 \\
\hline Prestige & 12 & 12 & 12 & 12 \\
\hline $\begin{array}{l}\text { Building Physical } \\
\text { Condition }\end{array}$ & 7 & 7 & 11 & 11 \\
\hline Security & 11 & 11 & 9 & 9 \\
\hline
\end{tabular}

Source: Analyzed

[Table 3] can indicate the ranking of MFI selection determinant factors as the credit place. The determinant factors of banking and nonbanking MFI has different sequence. Public Bank Micro Unit and Rural Bank are selected as credit place because the location is near to their residence (rank 1), great service (rank 2), administration speed (rank 3). While the selection of non-banking MFI (Cooperative and BMT) is influenced by administration speed factor (rank 1), location is near to public transportation (rank 2) and great service (rank 3).

\subsubsection{MFI selection power factors}

2 approach aspects which are used are SMME selection determinant factor towards MFI and credit requirement factor. Table 4 explains the requirements given by MFI to customers who will make a credit. The requirements will be sequenced based on the following MFI priority:

Table 4. The sequence of credit requirement priority of MFI towards customer candidate (SMME)

\begin{tabular}{|c|c|c|c|c|}
\hline & $\begin{array}{c}\text { Public Bank } \\
\text { Micro Unit }\end{array}$ & $\begin{array}{c}\text { Rural Bank } \\
\text { (BPR) }\end{array}$ & Cooperative & BMT \\
\hline Collateral & 3 & 3 & 4 & 4 \\
\hline Financial Statement & 2 & 2 & 5 & 5 \\
\hline Credit Proposal & 4 & 6 & 6 & 1 \\
\hline $\begin{array}{c}\text { Administrational } \\
\text { Comprehensiveness }\end{array}$ & 1 & 1 & 1 & 8 \\
\hline Incorporation Type & 8 & 8 & 8 & 2 \\
\hline Debtor's Character & 6 & 4 & 2 & 7 \\
\hline Credit Performance & 5 & 7 & 7 & 6 \\
\hline
\end{tabular}

Source: Analyzed

[Table 4] describes the sequence of credit requirement priority of MFI towards their customer candidate. Public Micro Bank Unit more prioritizes on administrational comprehensiveness requirement (rank 1), financial statement (rank 2), and collateral (rank 3). While BPR has rank or sequence 1 to 3 which is similar to Public Bank Micro Unit. However, debtor's character and personal insurance are selected as priority 4 and 5. It is different to BPR, 
Small and Middle Macro Enterprise (SME) Preference in Making Financing Source from Micro Financial Institutions (A Research on SME Preference Identification in Making Financing Source from Micro Financial Institutions)

Public Bank Micro Unit more emphasizes on the credit proposal and past performance of debtor candidate. Non banking MFIs (Cooperative, BMT) have different credit requirement priority sequence with banking MFIs (Public Bank Unit and BPR). The sequence of credit requirement priority seen from Cooperative and BMT perception is administrational comprehensiveness (rank 1), debtor's characteristics (rank 2) and personal insurance (rank 3)

\subsection{Aggregative discussion}

Aggregative discussion is performed to relate some analysis result and finding of the research. The relationship between finding results will be described aggregately and comprehensively. Aggregative discussion uses segmentation of 4 type of MFI (Public Bank Micro, BPR, Cooperative, and BMT) and analysis result and some findings point of view.

a. Public bank micro unit

In general, customers of Public Bank Micro Unit who moves in service sector with Y individual ownership and dominant revenue. Business scale which is owned is small scale. This business scale can be reflected in business expense and revenue higher than IDR 25,000,000 / month. On the other hand, customer average education level is less or equal to Bachelor Degree (S1). High relative customer education level and small business volume (higher than IDR 5 million) causes credit requirement more emphasizes on financial statement and collateral beside administrational requirement.

The presence of financial statement and collateral become general customers' character and business authentic evidence. Customers or customer candidates of Public Bank Micro Unit assume that its location is near to their residence and has good service. It becomes the determinant factor of Public Bank Micro Unit.

b. BPR

In general, BPR customers are in industrial sector with dominant individual ownership. This business scale can be reflected with business expense and monthly revenue between IDR 1525 million. On the other hand, the average education level of customers is more or less or equal to Senior High School. Standard customers' education level and small business volume (higher than IDR 5 million) cause credit priority requirement towards the customers more emphasizes on financial statement and collateral beside administrational requirement. Customers. Customers or customer candidates of BPR assume that the BPR location is near to their residence and provides good service.

c. Cooperative

In general, Cooperative customers move in service sector with dominant individual ownership. Business scale which is possessed in included in micro scale. This business scale can be reflected with monthly business expense IDR 5 million - 15 million and revenue lower than IDR 5 million. On the other side, the customers' average education level is lower than or equal to Senior High School. Standard customers' education level and business volume is categorized as micro business (lower than 5 million) causes credit priority requirement towards the customers more emphasizes on personal insurance and debtor's characters beside administrational requirement. Cooperative will not use strict requirement but emphasizes on personal trust and insurance. Cooperative customers assume that cooperative has fast administration and good service so that the credit easily realized.

d. BMT

In general, BMT customers move in service sector with dominant personal ownership. The business scale is micro. It can be reflected that their business revenue and expense is lower than 5 million per month. On the other side, the customers' average education level is lower than or 
equal to Senior High School. The standard customers' education level micro business volume (lower than IDR 5 million) cause the credit priority requirement to customers more emphasizes on personal insurance and debtor's characters other than administrational requirement. BMT does not use strict requirement but emphasizes on trust and personal insurance. Customers or customer candidates of BMT perceive that BMT has fast administration and good service so the credit application can be easily realized.

\section{Conclusion}

A. SMME profile which become MFI customers has different and segmented characteristics based on MFI.

a. The segmentation of Public Bank Micro Unit MFI is SMME which is categorized as small enterprise and has business revenue that is higher than IDR 25 million with individual revenue level which is higher than IDR 10 million and various business owner's education level from Elementary School to University.

b. The segmentation of Rural Bank (BPR) MFI is small scale SMME that has IDR 15-25 million as their business revenue, the individual revenue level is IDR 5-10 million, and lower education level or equal to Senior High School prefer Rural Bank (BPR) for credit.

c. The segmentation of MFI Cooperative is SMME which is categorized as micro enterprise scale and has business revenue lower than IDR 5 million. The individual's revenue level is IDR 1-5 million, lower education level or equal to Senior High School prefer cooperative for credit.

d. The segmentation of MFI BMT is SMME which is categorized as micro enterprise scale and has business revenue lower than IDR 5 million. The individual's revenue level is lower than IDR 1 million, lower education level or equal to Senior High School prefer BMT for credit.

B. The determinant factor of MFI selection which is performed by customer (SMME) on each MFI forms the segmentation as follows:

a. Public Bank Micro Unit Factor as the credit provider because they assume that it provides good service with administrational speed (easiness), even Private Bank Micro Unit is considered to be affordable from location side.

b. Cooperative selection determinant factor is good service with administrational speed and near location to public transportation factor.

c. BMT selection determinant factor is relative similar to Cooperative customer segment, which is good service factor with administrational speed (easiness) and near location to public transportation.

C. The Segmentation of SMME preference towards each MFI is caused by some things as follow (selection power factor):

a. Public Bank Micro Unit MFI. They select their characteristics as follow: they are accustomed to connecting with bank; more oriented on business development; accustomed to filling credit format, required administrational comprehensiveness; have collateral; and other requirements which are required by the bank.

b. Selection power toward Rural Bank (BPR) MFI. They select their characteristics as follow: they are accustomed to connecting with BPR; their orientation more emphasizes on work capital addition; simple format filling and administrational process; and more flexible collateral. 
c. Selection power towards Cooperative MFI. They select their characteristics as follow: they are accustomed to connecting with cooperative; very simple administration and fast time; emotional relationship between customer and cooperative; and more flexible collateral.

d. Selection power towards BMT MFI. They select their characteristics as follow: relative strong religious level; emotional relationship between customer and BMT and administrational speed (easiness).

D. MFI point of view in selecting customers can be reviewed from requirement side in providing credit.

e. Public Bank Micro Unit selection emphasizes on administrational comprehensiveness, financial statement and collateral as the requirements of credit application. It is appropriate with volume condition and business scale segmentation, even with revenue and education level.

f. Rural Bank selection power emphasizes on administrational, financial statement and collateral as the requirements of credit application. It is appropriate with volume segmentation and business scale, or even with their education and revenue level. However, BPR has a little bit different consideration compared to Public Bank Micro Unit. They pay more attention to personal character and insurance compared to their credit application and performance as emphasized by Public Bank Micro Unit.

g. It indicates that Rural Bank (BPR) adjusts with their customer's profile segment in different manner to Public Bank Micro Unit customers seen from their business revenue side.

h. Cooperative MFI selection power emphasizes on the requirements of administrational comprehensiveness, customers' characters and collateral of credit applicant. It is appropriate with volume condition segmentation and business scale, even with their revenue and education level. It indicates that cooperative tries to get customers from micro business segment whose revenue lower than IDR 5 million.

i. BMT MFI selection power emphasizes on requirements of administrational comprehensiveness, customers' characters and collateral of credit applicant. It is appropriate with volume condition segmentation and business scale, even with their revenue and education level. It indicates that BMT tries to get customers from micro business segment whose revenue lower than cooperative customers, which is < IDR 1 million.

\section{References}

[1] M. A. Seligson and S. Kuznets, "Economic Growth and Income Inequality," in The Gap between Rich and Poor, (2019)

[2] E. Aryeetey, A. Baah-Nuakoh, T. Duggleby, H. Hettige, and W. F. Steel, "Supply and demand for finance of small enterprises in Ghana," World Bank Discuss. Pap., (1994)

[3] World Bank, "Global Survey of Development Banks," Policy Res. Work. Pap., (2012)

[4] N. M. P. Bocken, S. W. Short, P. Rana, and S. Evans, "A literature and practice review to develop sustainable business model archetypes," Journal of Cleaner Production. vol.65, pp 42-56, (2014) DOI: 10.1016/j.jclepro.2013.11.039.

[5] H. Saranga and R. Nagpal, "Drivers of operational efficiency and its impact on market performance in the Indian Airline industry,” J. Air Transp. Manag., vol.53, pp.165-176, (2016) DOI: 10.1016/j.jairtraman.2016.03.001.

[6] T. A. Koszalka, D. F. Russ-Eft, R. Reiser, F. A. S. [Col] Canela, B. L. [Col] Grabowski, and C. J. [Col] Wallington, "Instructional designer competencies: The standards (4th ed.).," Instructional designer competencies: The standards (4th ed.), (2013) 
[7] G. Hilson, "Small-scale mining and its socio-economic impact in developing countries," Nat. Resour. Forum, (2002) DOI: 10.1111/1477-8947.00002.

[8] A. Ates, P. Garengo, P. Cocca, and U. Bititci, "The development of SME managerial practice for effective performance management," Journal of Small Business and Enterprise Development. vol.20, no.1, pp.28-54, (2013) DOI: 10.1108/14626001311298402.

[9] C. F. Sabel, "Flexible Specialisation and the Re-Emergence of Regional Economies," in Post-Fordism, (2008)

[10] A. Nicholls and A. H. Cho, "Social Entrpreneurship: The Structuration of a field," in SOCIAL ENTREPRENEURSHIP New Models of Sustainable Social Change, (2006)

[11] R. Cerchione and E. Esposito, "Using knowledge management systems: A taxonomy of SME strategies," Int. J. Inf. Manage., vol.37, no.1, pp.1551-1562, (2017) DOI: 10.1016/j.ijinfomgt.2016.10.007.

[12] C. Martins, T. Oliveira, and A. Popovič, "Understanding the internet banking adoption: A unified theory of acceptance and use of technology and perceived risk application,” Int. J. Inf. Manage., vol.34, no.1, pp.1-13, (2014) DOI: 10.1016/j.ijinfomgt.2013.06.002.

[13] M. A. Taiwo, A. M. Ayodeji, and B. A. Yusuf, "Impact of Small and Medium Enterprises on Economic Growth and Development,” Am. J. Bus. Manag., vol.1, no.1, pp.18-22, (2013) DOI: 10.11634/21679606170644.

[14] Haeruddin Saleh and Muhammad Idris, "Determinant Factors of Entrepreneurial Intention (Case Study of Management Student, Bosowa University),” J. Eng. Appl. Sci., vol.14, no.7, pp.2163-2170, (2019) DOI: 10.3923/jeasci.2019.2163.2170.

[15] C. A. Paulus and A. Fauzi, "Factors Affecting Sustainability of alternatives livelihood in coastal community of Nembrala East Nusa Tenggara: An Application of MICMAC Method,” J. Ekon. Pembang. Kaji. Masal. Ekon. dan Pembang., vol.18, no.2, pp.175-182, (2017) DOI: 10.23917/jep.v18i2.4397.

[16] M. Lind and G. Goldkuhl, "How to Develop a Multi-Grounded Theory: the evolution of a business process theory,” Australas. J. Inf. Syst., vol 13, no.2, (2006) DOI: 10.3127/ajis.v13i2.41.

[17] D. L. McFadden, "Conditional Logit Analysis of Qualitative Choice Behavior," in Frontiers in Econometrics, (1974)

[18] O. Weber and B. Feltmate, Sustainable banking: Managing the social and environmental impact of financial institutions, (2016)

[19] J. Morduch and B. Haley, "Analysis of the effects of microfinance on poverty reduction. Ottawa: RESULTS, Canada, for the Canadian International Development Agency,” NYU Wagner - Work. Pap. Ser., 2001, DOI: September, (2015)

[20] S. Mago and S. Chitokwindo, "The impact of mobile banking on financial inclusion in Zimbabwe: A case for Masvingo province,” Mediterr. J. Soc. Sci., vol.5, no.9, pp.221, (2014) DOI: 10.5901/mjss.2014.v5n9p221.

[21] S. B. Banerjee and L. Jackson, "Microfinance and the business of poverty reduction: Critical perspectives from rural Bangladesh,” Hum. Relations, vol.70, no.1, pp.63-91, (2017) DOI: 10.1177/0018726716640865. 
Small and Middle Macro Enterprise (SME) Preference in Making Financing Source from Micro Financial Institutions (A Research on SME Preference Identification in Making Financing Source from Micro Financial Institutions)

This page is empty by intention. 